\title{
A Study of Inertia Welding: The Sensitivity
} of Weld Configuration and Strength to Variations in Welding Parameters

$$
\begin{aligned}
& \text { DO NOT MICROFILM } \\
& \text { COVER }
\end{aligned}
$$

M. W. Mote

Prepared by Sandia National Laboratories, Albuquerque, New Mexico 87185 and Livermore, California 94550 for the United States Department of Energy under Contract DE-AC04-76DP00789.

Printed Decembor. 1981

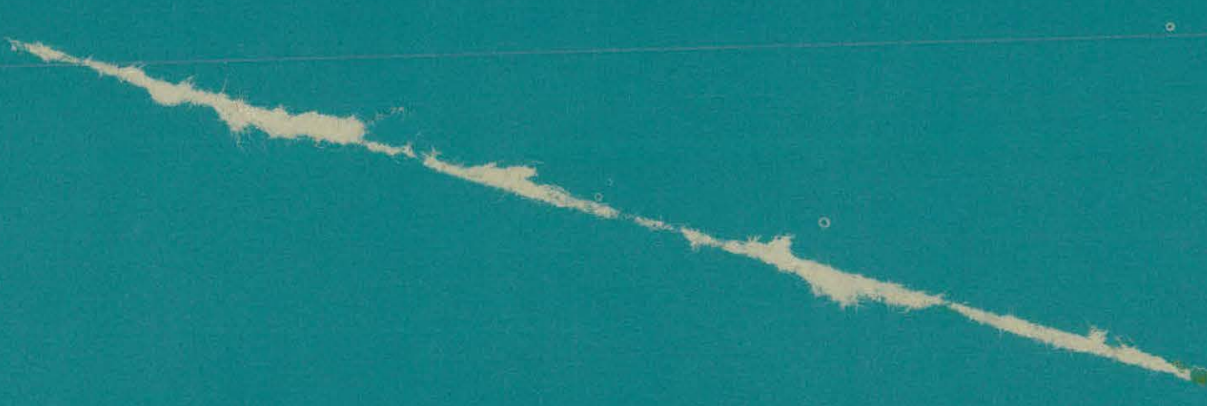




\section{DISCLAIMER}

This report was prepared as an account of work sponsored by an agency of the United States Government. Neither the United States Government nor any agency Thereof, nor any of their employees, makes any warranty, express or implied, or assumes any legal liability or responsibility for the accuracy, completeness, or usefulness of any information, apparatus, product, or process disclosed, or represents that its use would not infringe privately owned rights. Reference herein to any specific commercial product, process, or service by trade name, trademark, manufacturer, or otherwise does not necessarily constitute or imply its endorsement, recommendation, or favoring by the United States Government or any agency thereof. The views and opinions of authors expressed herein do not necessarily state or reflect those of the United States Government or any agency thereof. 


\section{DISCLAIMER}

Portions of this document may be illegible in electronic image products. Images are produced from the best available original document. 
Issued by Sandia Laboratories, operated for the United States Department of Energy by Sandia Corporation.

\section{NOTICE}

This report was prepared as an account of work sponsored by the United States Government. Neither the United States nor the United States Department of Energy, nor any of their employees, nor any of their contractors, subcontractors, or their employees, makes any warranty, express or implied, or assumes any legal liability or responsibility for the accuracy, completeness or usefulness of any information, apparatus, product or process disclosed, or represents that its use would not infringe privately owned rights. 


\section{PAGES 1 to 2 WERE INTENTIONALLY LEFT BLANK}


SAND81-8029

Unl imited Release

Printed December 1982

A STUDY OF INERTIA WELDING: THE SENSITIVITY OF WELD CONFIGURATION AND STRENGTH TO VARIATIONS IN WELDING PARAMETERS

M. W. Mote

Materials Development Division I

Sandia Laboratories, Livermore

$$
\text { SAND }--81-8029
$$

- DE82 011188

Sandia Laboratories, Livermore

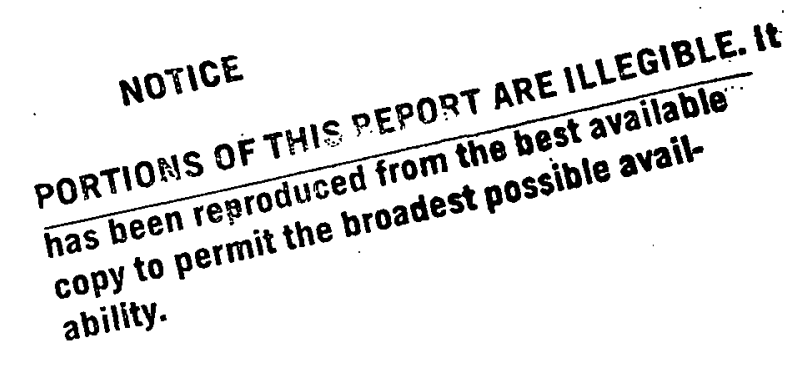

ABSTRACT

We report on an experiment designed to demonstrate the forgiveness of inertia welding, that is, the relative insensitivity of weld strength to variations in energy (rotational speed of parts) and axial force. Although easily observed variations in the welding parameters produced easily observed changes in weldment configuration and changes in dimension (upset), only extremes in parameters produced changes in weld strength. Consequently, process monitoring and product inspection would be sufficient for quality assurance in a production environment.

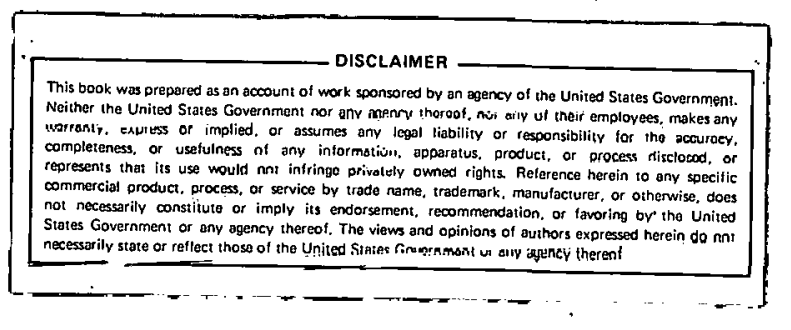

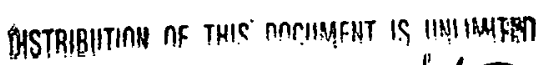

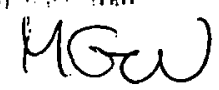




\title{
A STUDY OF INERTIA WELDING: THE SENSITIVITY OF WELD CONFIGURATION AND STRENGTH TO VARIATIONS IN WELDING PARAMETERS
}

\author{
Introduction
}

The earliest of metal welding processes was deformation welding: two pieces of gold placed together and hammered until the interface between them disappeared. Iron resisted this kind of welding until fluxes were found to dissolve the oxides which formed at the higher temperatures required to render the iron as malleable as gold is at ambient temperatures. Blacksmiths have been making such welds at least since early in the Iron Age.

The most recently developed form of deformation welding is known as friction welding, with inertia welding as a subclass. In friction welding at least one of the two parts must include a surface of revolution. The parts are friction heated by rotating one with respect to the other while driving the two parts together, and the heating continues until one or both parts contain a sufficient volume of hot (but still solid) metal. The hot metal is deformed in such a way as to expel any oxides or contaminants from the interface, thus effecting a metallurgical bond.

In inertia welding, the energy required to heat the metal is stored in a rotating mass (flywheel plus tooling plus part), and is dissipated as the parts are brought together, heated, and welded, with the new weld joint finally stopping the rotating mass. Its proponents tout its simplicity, repeatability, and reliability in contrast to fusion welding processes, and even in contrast to "direct drive" friction welding, wherein the power to the rotating mass is left engaged through the heating phase, the rotation is stopped by a brake, and the upsetting deformation accomplished by the axial thrust. The four phases of friction welding--acceleration, engagement, upset, and stopping-are depicted in Figure 1, al though for inertia welding the last three occur without pause or transition.

While the process is limited to essentially circular welds, it has potential for a wide range of "nonweldable" combinations as well as for inexpensive, high-quality welds in a broad range of ordinary materials. With these characteristics the process is finding rapidly increasing use in automotive, agricultural, aircraft, and heavy-duty machine manufacture for an extensive variety of parts.1-4 The only apparently insurmountable limitation arises with materials containing lubricating phases such as the graphite in cast iron and the lead in machinable grades of brasses, because the lubrication provided by these phases prevents adequate frictional heating. 

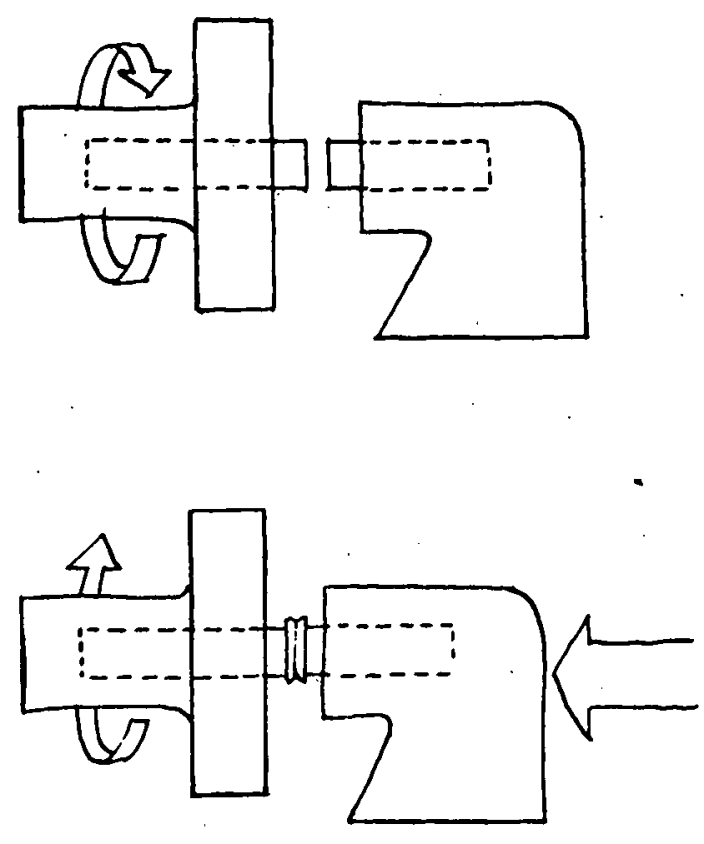
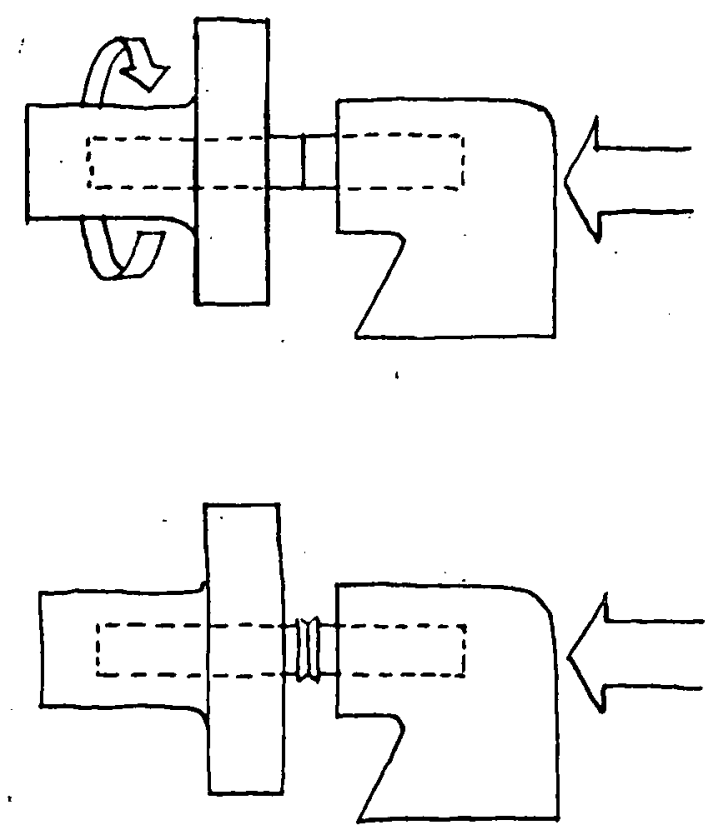

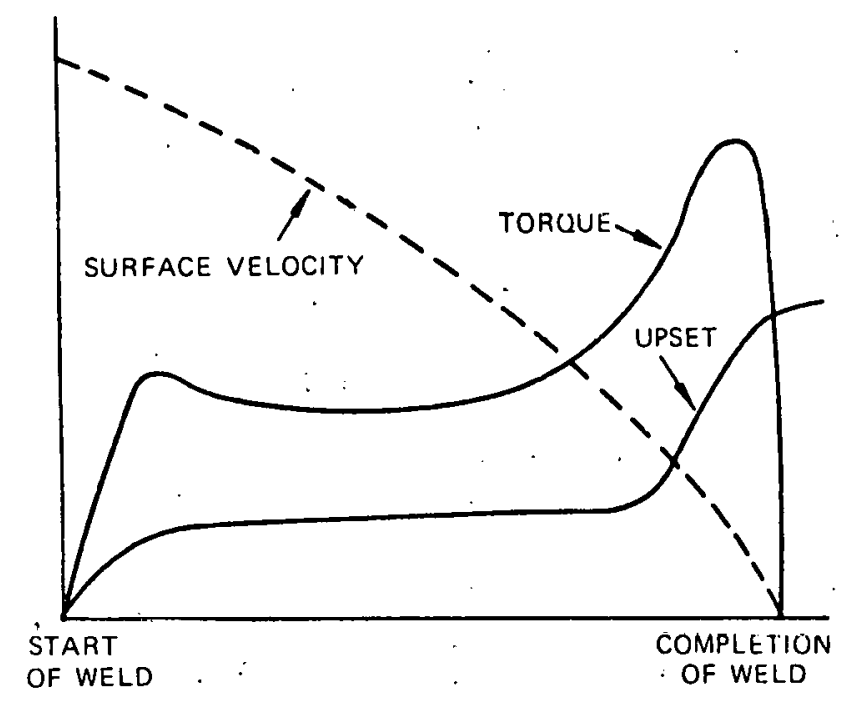

Figure 1. The Steps in Inertia Welding and the Relationship between Velocity, Torque, and Upset Deformation

Sandia's interest in the process derives from its ability to join "unweldable" combinations and from its ability to make superior quality welds for very critical service. Sandia is currently studying a number of applications which fit these conditions. These include solid copper to stainless steel tubing, aluminum to stainless steel tubing, titanium alloy to copper, and high strength steels and tool steel to high strength steels. 
In choosing any process it is only prudent to consider methods of evaluating the product. Over the years, the technical community has come to rely on a number of nondestructive evaluation (NDE) methods for accepting conventionally welded joints. These include proof testing (mechanically or hydrostatically for strength), radiography (for voids, lack of penetration, lack of fusion, and inclusions in fusion welds and brazes), and sound waves (for discontinuities in fusion welds and brazes).

In industry, however, friction welding is generally considered so reliable that destructive evaluation is used to establish welding parameters, and product acceptance is based on monitoring the welding parameters, a simple thing to do. In critical welds some producers use ultrasound to evaluate inertia welds, particularly on rotating parts, but report that they seldom observe anything but a rare defect in the starting stock, re-oriented or enlarged by the deformation during welding. The concensus in the industry is, "parts never fail in the weld."

Generally, the degree of concern expressed in the details of evaluation procedures is a function of the likelihood of finding rejects. If a process is highly repeatable, seldom if ever produces defective parts, and is easy to control within acceptable limits, then little evaluation of a product is called for even for a high degree of reliability. Such claims are made for inertia welds. Furthermore, it is claimed that the process is so forgiving that strong welds are made even with parameters varying greatly from the ideal.

Here we report on an experiment designed to demonstrate this process forgiveness and to gain some experience that will help us feel comfortable in relying on process monitoring for product acceptance. We have al ready been convinced that existing. NDE techniques are of limited use in evaluating inertia welds. Moreover, for some of our joints, nondestructive proof testing is out of the question because the strength of the joint exceeds the capacity of any universal testing machine.

One nondestructive evaluation that is peculiar to this process, and is reportedly highly reliable as a measure of process repeatability, and thereby product reliability, is the amount of shortening or upset achieved in making the joint. If the joint is visible (i.e., not hidden within the finished assembly) the configuration of the extruded metal reflects that amount of upset. In any case, measurements before and after can confirm the amount of upset. This method appears to be the most consistently used product acceptance criterion.

\section{Description of the Experiment}

We asked Manufactoring Technolgy, Inc * to weld specimen pairs of a variety of materials of potential interest to Sandia designers (see Table I), al though not all of the materials are being actively explored at present. For each of the selected pairs, the contractor was required to choose, after a few trial

*Mi shawaka, Indiana. 
welds, a set of parameters for flywheel mass, rotating speed, and axial force expected to produce a good weld. This set was used to make eight weldments for which we could observe the reproducibility of the process.

\section{TABLE I}

SPECIMEN PAIRS FOR INERTIA WELDING STUDIES

\begin{tabular}{|c|c|c|c|c|c|}
\hline \multirow[b]{2}{*}{ Material } & \multicolumn{2}{|c|}{ Size (inches) a } & \multicolumn{2}{|c|}{ Size (inches) } & \multirow[b]{2}{*}{ Material } \\
\hline & $0 . \mathrm{D}$. & Thick. & 0.0. & Thick. & \\
\hline 4330 & 1 & $1 / 8$ & 1 & $1 / 8$ & HP 9-4-20 \\
\hline 316 & 1 & $1 / 8$ & $1-1 / 8$ & $1 / 4$ & $6061-T 6$ \\
\hline 316 & 1 & $1 / 8$ & $1-1 / 8$ & $1 / 4$ & copper \\
\hline$T i-6-6-2$ & $7 / 8$ & $1 / 8$ & $15 / 16$ & $3 / 16$ & red brass \\
\hline$A-286$ & 1 & $1 / 8$ & 1 & $1 / 8$ & $A-286$ \\
\hline$A-286$ & 1 & $1 / 8$ & 1 & $1 / 8$ & 316 SS \\
\hline $7075-T 6$ & 1 & $1 / 8$ & 1 & $1 / 8$ & $7075 \mathrm{~T} 6$ \\
\hline $21-6-9$ & 1 & $1 / 8$ & 1 & $1 / 8$ & HP $9-4-20$ \\
\hline tool steel & 1 & $1 / 8$ & $1-1 / 8$ & $1 / 4$ & 4330 \\
\hline 2024-T6 & 1 & $1 / 8$ & 1 & $1 / 8$ & 2024-T6 \\
\hline
\end{tabular}

Then the contractor was required to make welds with parameters deliberately and systematically varied from those for the "good" welds. It was our goal to make "bad" welds at both extremes of energy and axial force. Judging by the breaking stress, we were successful in making "bad" welds only about half the time.

Energy was changed only by changing revolutions per minute, the argument being that once a flywheel is chosen and bolted on it will not be changed inadvertently. Speed and axial force are operational controls and can vary due to malfunctioning controls or errors on the part of the operator. (Those in industry are quick to point out that rpm and axial force can be monitored readily, permitting the immediate rejection of substandard welds.) 
For the specimen configuration we chose hollow cylinders sized to fit standard collets on the contractor's machines. Each cylinder was four inches long with a diameter and wall thickness as shown in Table I. When the materials were known or expected to be equally strong at the welding temperature, the wall thickness was the same for each part. When one material was weaker than the other, we judiciously increased its wall thickness to increase the load it could sustain and assure a sweep of the softer material past the surface of the harder.

While surface preparation is not generally critical when using inertia welding, some care was taken in the interest of consistency. The aluminum samples, except in 2, were polished with silicon carbide paper just before welding. All the heat-treated steels were faced on a lathe to remove the scale from the weld face. The stainless steels were simply wiped with a clean rag, their surfaces having been machined earlier. In addition, the three items that combined materials of vastly different strengths at welding temperatures (Items 2, 3, and 4) were prepared with great care before welding: Experience has shown that a freshly machined surface free of all contaminants, including fingerprints, is necessary to produce consistently satisfactory welds in cases such as these.

The welding operation subjects the material near the weld interface to severe and rapid temperature changes. Care must be exercised in many cases in heat treating the starting stock and finished weldments to maximize the performance of the weldment. We chose to 1 imit post-weld heat treatment to that required to restore the heat-affected zone to near optimum properties and leave the rest of the sample unchanged. Therefore, where appropriate, starting stock was heat treated to the desired strength level before welding. Pre- and post-welding heat treatments are described in Table II.

Because the actual welding was accomplished at some elevated temperature, it is not likely that the heat treatment condition at the time of welding influenced welding behavior This may not have been entirely true for the titanium alloy because some welders have had much better success with a softer alloy or heat treatment. However, the application we were interested in required a high strength in the titanium.

\section{Experimental Results}

The principal question in evaluating this experinment is "How readily can we identify those weldments made with parameters different from the design level?" A secondary question of considerable importance is "How bad can they look (or be) and still meet engineering requirements?" We chose to answer the first question as industry does: by appearance of the weld expulsion and by the amount of shortening or upset. We addressed the second question by pulling the weldments in tension and calculating a fracture stress, a method deemed to be slightly more quantitative than the typical welder's bent-weldment test. 
TABLE II

HEAT TREATMENT OF STOCK AND WELDMENTS

BEFORE. AND AFTER INERTIA WELDING

\begin{tabular}{|c|c|c|c|c|c|}
\hline No. & Material 1 & $\begin{array}{c}\text { Preweld } \\
\text { Heat Treatment } \\
\end{array}$ & Material 2 & $\begin{array}{c}\text { Preweld } \\
\text { Heat Treatment }\end{array}$ & $\begin{array}{c}\text { Weldment } \\
\text { Heat Treatment }\end{array}$ \\
\hline 1 & $4330 \mathrm{~V}$ & $\begin{array}{lll}1550^{\circ} \mathrm{F}, & 0 Q & \& \\
\text { Temp to } & \mathrm{RC} & 40\end{array}$ & HP $9-4-20$ & $\begin{array}{lll}1550^{\circ} \mathrm{F}, & 0 Q & \& \\
\text { Temp to } & \text { Rc } & 40\end{array}$ & $4 \mathrm{~h} \dot{\mathrm{\theta}} 1025^{\circ} \mathrm{F}$ \\
\hline 2 & 316 SS & $\begin{array}{l}\text { As received } \\
\text { (annealed) }\end{array}$ & $6016-T 6$ & $\begin{array}{l}\text { As received } \\
(T-651)\end{array}$ & $8 \mathrm{~h} \odot 350^{\circ} \mathrm{F}$ \\
\hline 3 & 316 SS & $\begin{array}{l}\text { As received } \\
\text { (annealed) }\end{array}$ & Copper & $\begin{array}{l}\text { As received } \\
\text { (annealed) }\end{array}$ & None \\
\hline 4 & $T i-6 A 1-6 V-2 S n$ & $\begin{array}{l}\text { Sol'n treat \& } \\
\text { aged; } 150 \text { ksi } \\
\text { UTS }\end{array}$ & Red Brass & $\begin{array}{l}\text { As received } \\
\text { (annealed) }\end{array}$ & None \\
\hline 5 & A-286 SS & $\begin{array}{l}\text { Sol'n treat }+ \\
\text { ppt harden } \\
16 \text { h } 01325^{\circ} \mathrm{F}\end{array}$ & $A-286$ SS & $\begin{array}{l}\text { Sol'n treat }+ \\
\text { ppt harden } \\
16 \text { h } 01325^{\circ} \mathrm{F}\end{array}$ & $16 \mathrm{~h} \odot 1325^{\circ} \mathrm{F}$ \\
\hline 6 & $A-286$ SS & $\begin{array}{l}\text { Sol'n treat + } \\
\text { ppt harden } \\
16 \text { h } 01325^{\circ} \mathrm{F}\end{array}$ & 316 SS & $\begin{array}{l}\text { As received } \\
\text { (annealed) }\end{array}$ & $16 \mathrm{~h} \odot 1325^{\circ} \mathrm{F}$ \\
\hline 7 & $7075-T 6$ & $\begin{array}{l}\text { As received } \\
(T-651)\end{array}$ & $7075-\mathrm{T} 6$ & $\begin{array}{l}\text { As received } \\
(T-651)\end{array}$ & $22 \mathrm{~h} @ 250^{\circ} \mathrm{F}$ \\
\hline 8 & $21-6-9$ SS & $\begin{array}{l}\text { As received } \\
\text { (annealed) }\end{array}$ & HP $9-4-20$ & $\begin{array}{lll}1550^{\circ} \mathrm{F}, & \mathrm{OQ} & \& \\
\text { Temp to } & \mathrm{RC} & 40\end{array}$ & $4 \mathrm{~h} \odot 1025^{\circ} \mathrm{F}$ \\
\hline 9 & $\begin{array}{l}\text { S-5 Tool } \\
\text { Steel }\end{array}$ & $\begin{array}{lll}1650^{\circ} \mathrm{F}, & 0 Q & \& \\
\text { Temp to } & \text { Rc } & 55\end{array}$ & $4330 \mathrm{~V}$ & $\begin{array}{lll}1550^{\circ} \mathrm{F}, & \mathrm{OQ} & \& \\
\text { Temp to } & \mathrm{RC} & 40\end{array}$ & $\begin{array}{l}2 \mathrm{~h} \odot 500^{\circ} \mathrm{F}+ \\
2 \mathrm{~h} \propto 500^{\circ} \mathrm{F}\end{array}$ \\
\hline 10 & 2024-T6 & $\begin{array}{l}\text { As received } \\
(T-651)\end{array}$ & 2024-T6 & $\begin{array}{l}\text { As received } \\
(T-651)\end{array}$ & $8 \mathrm{~h} \theta 350^{\circ} \mathrm{F}$ \\
\hline
\end{tabular}

Figures 2 through 11 portray the variation in weldment configuration as a result of variation in weld parameters. In the center of each picture is one of the eight weldments made using the "optimum". or "design" parameters of surface speed, flywheel mass, and axial force. In the upper left are shown samples made with the same optimum force but with two levels of increased energy $(\mathrm{rpm})$. In the lower left are samples made with optimum force and two levels of decreased energy. On the right are samples made with optimum energy, the upper two with increased loads, the lower two with decreased loads. The numbers in the picture beside each sample are the decimal fractions of the "optimum" of energy or load. 

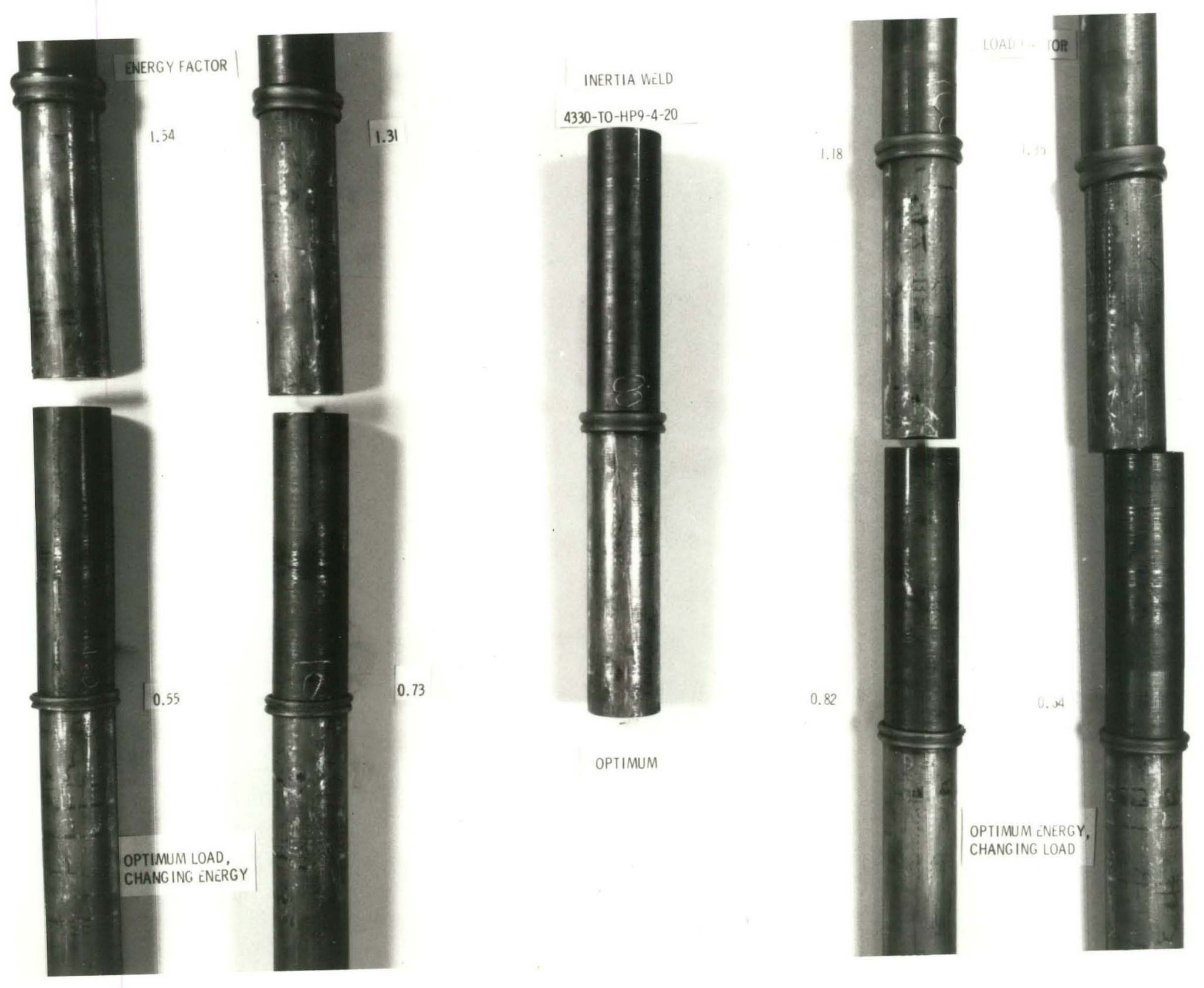

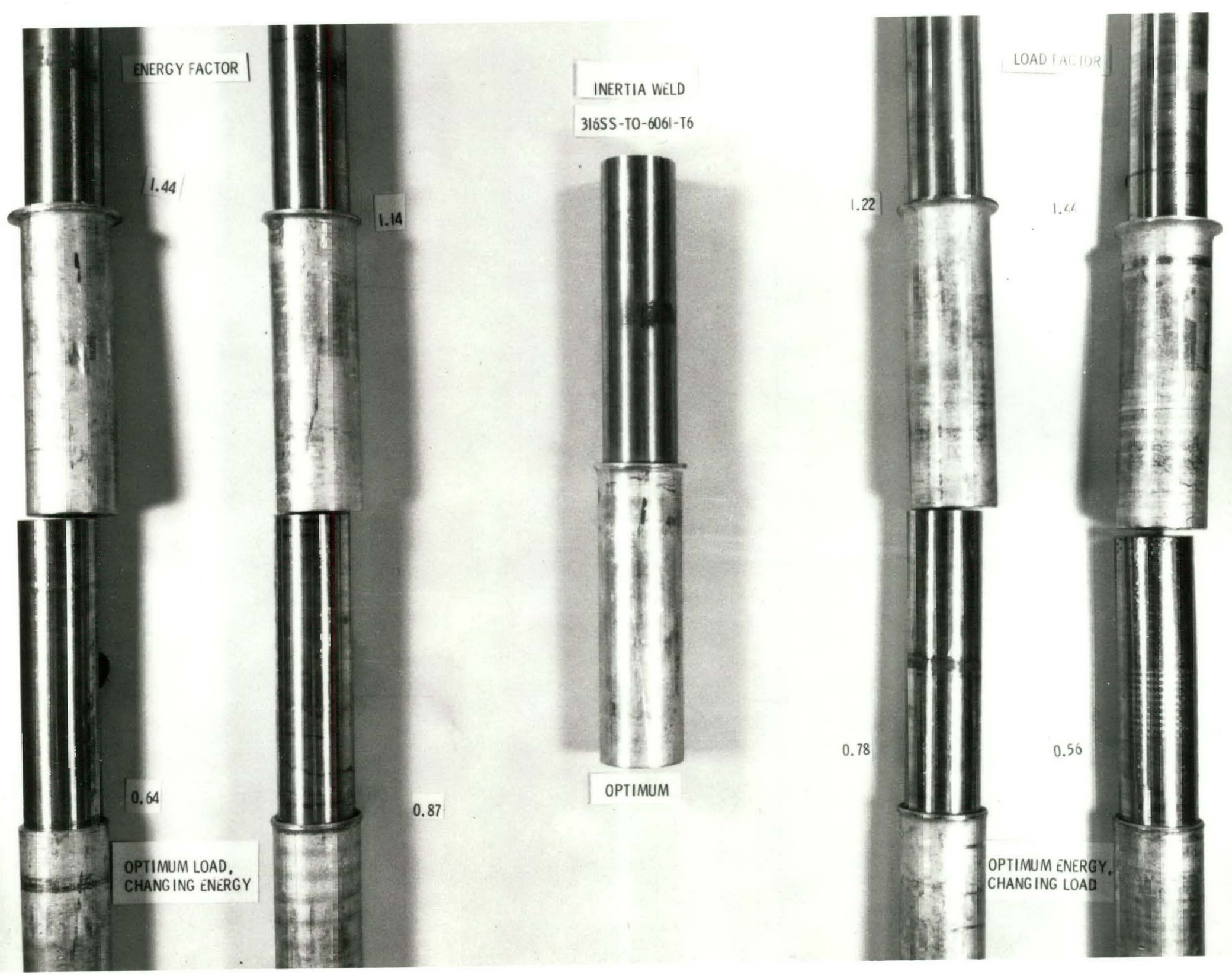

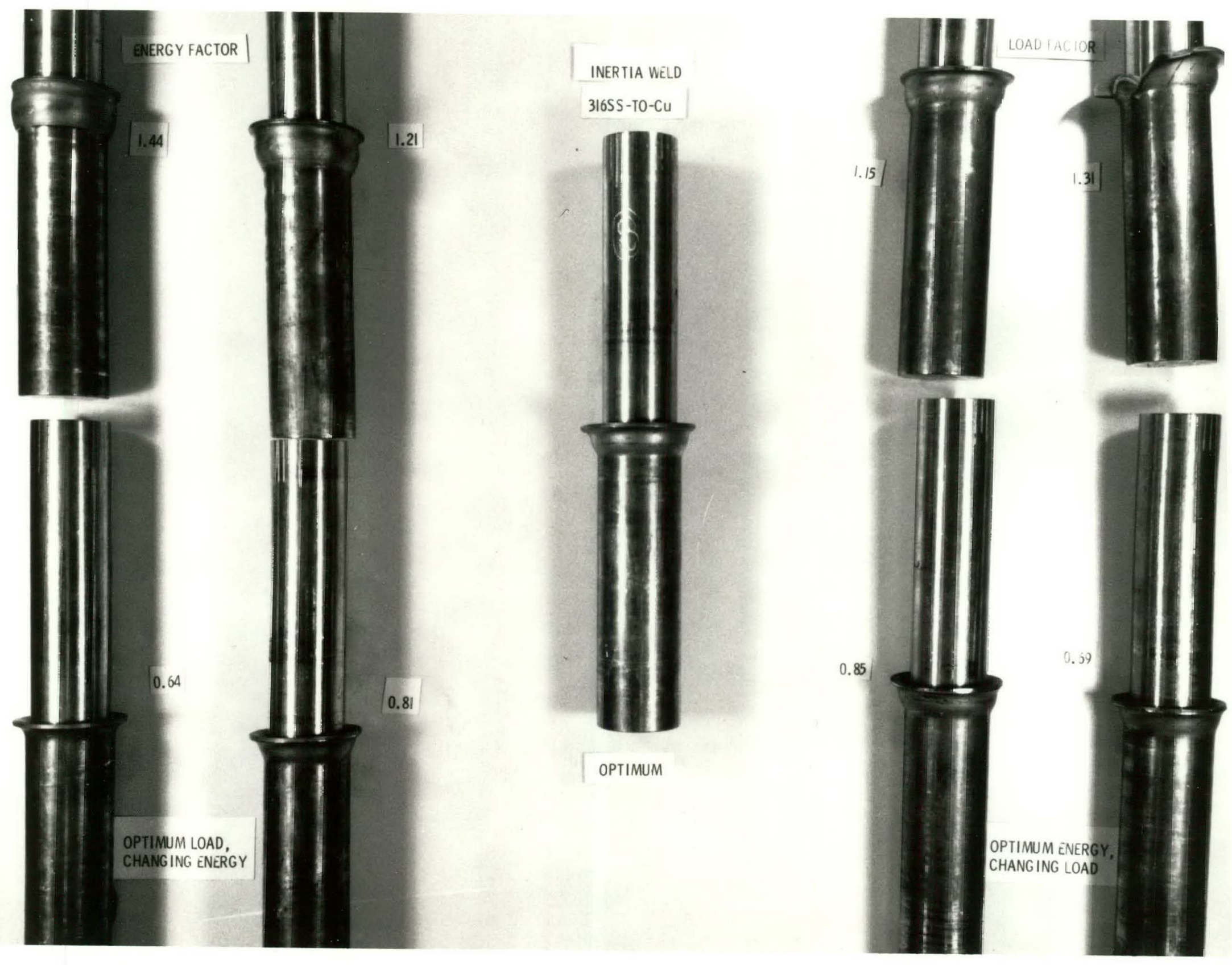

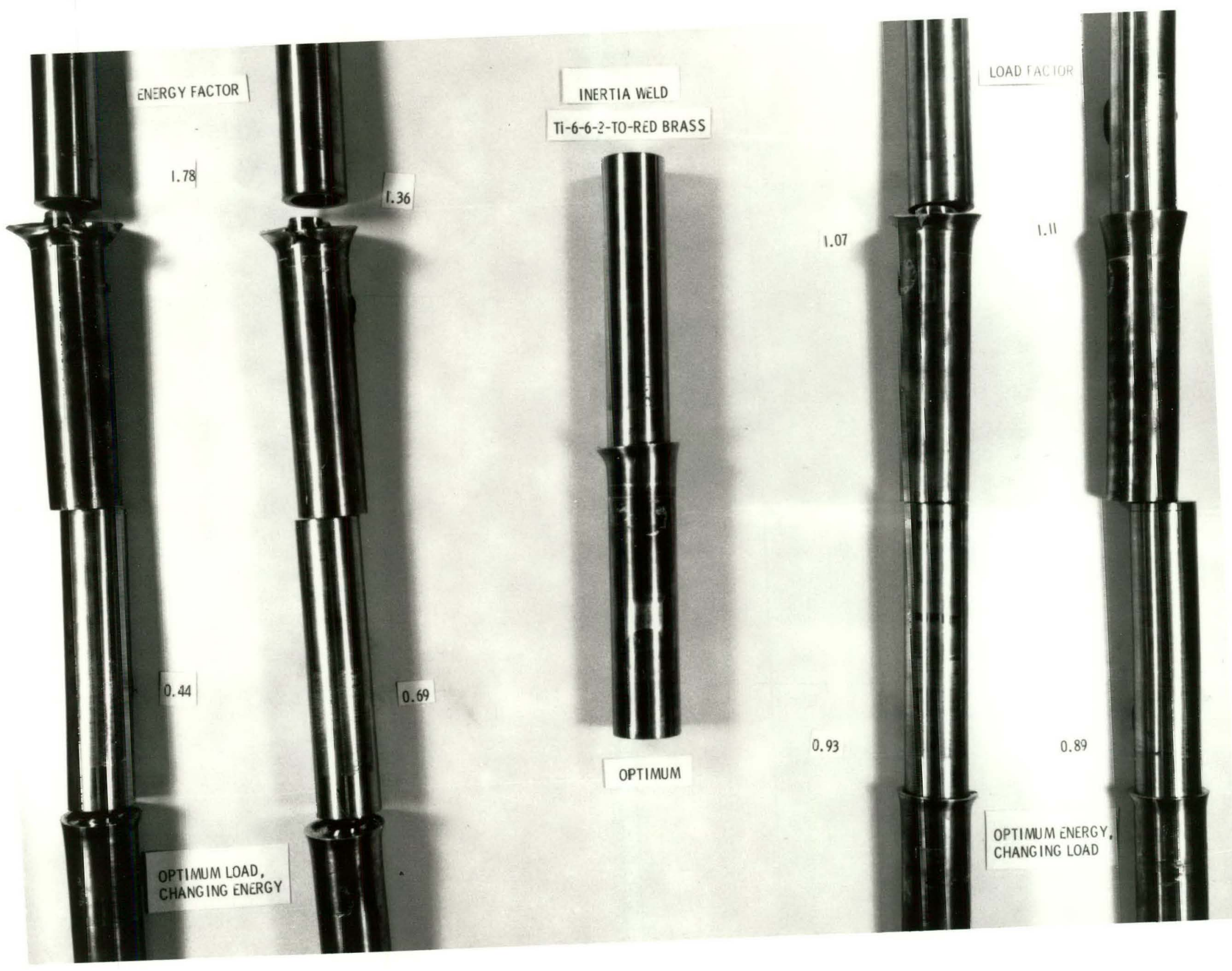

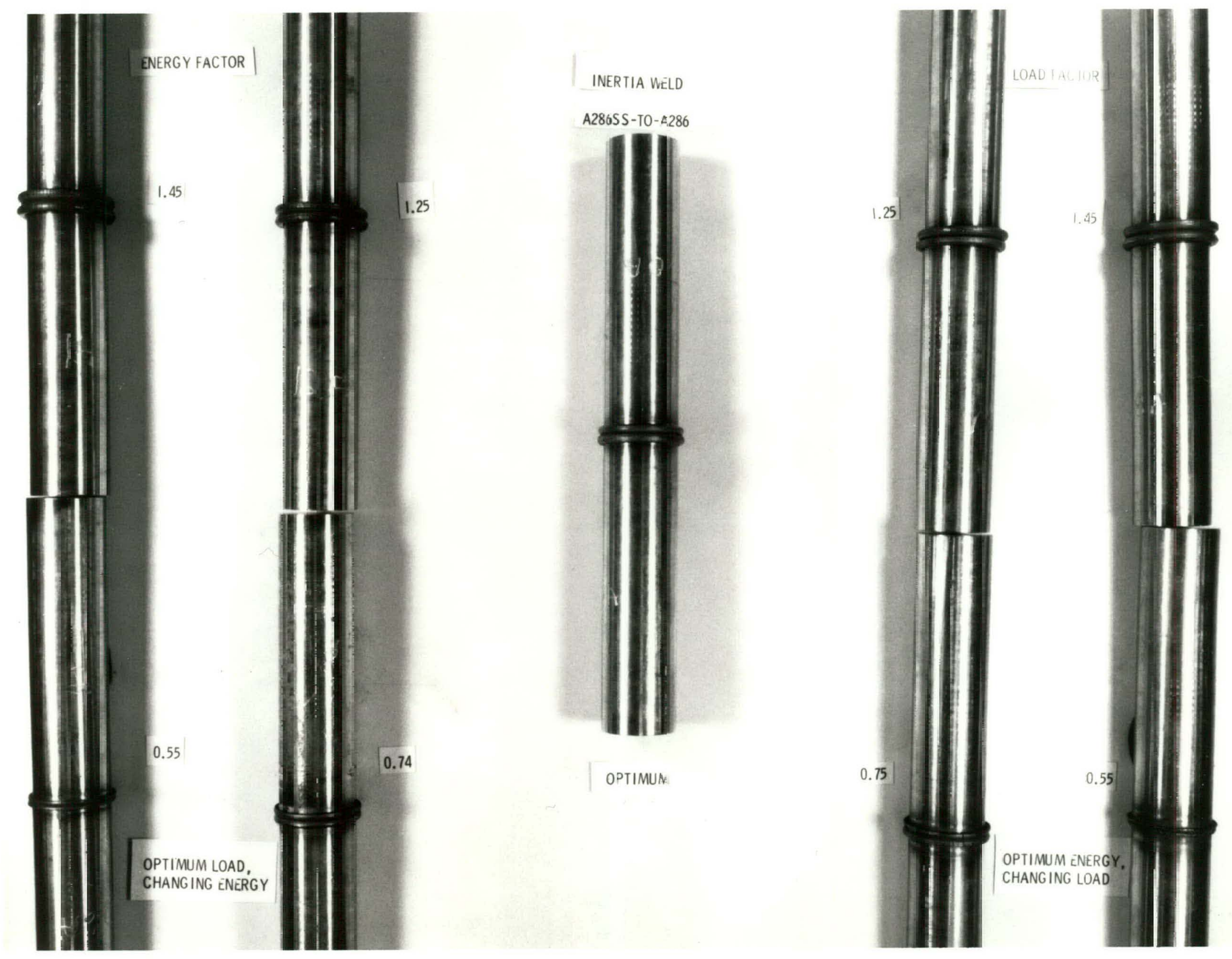

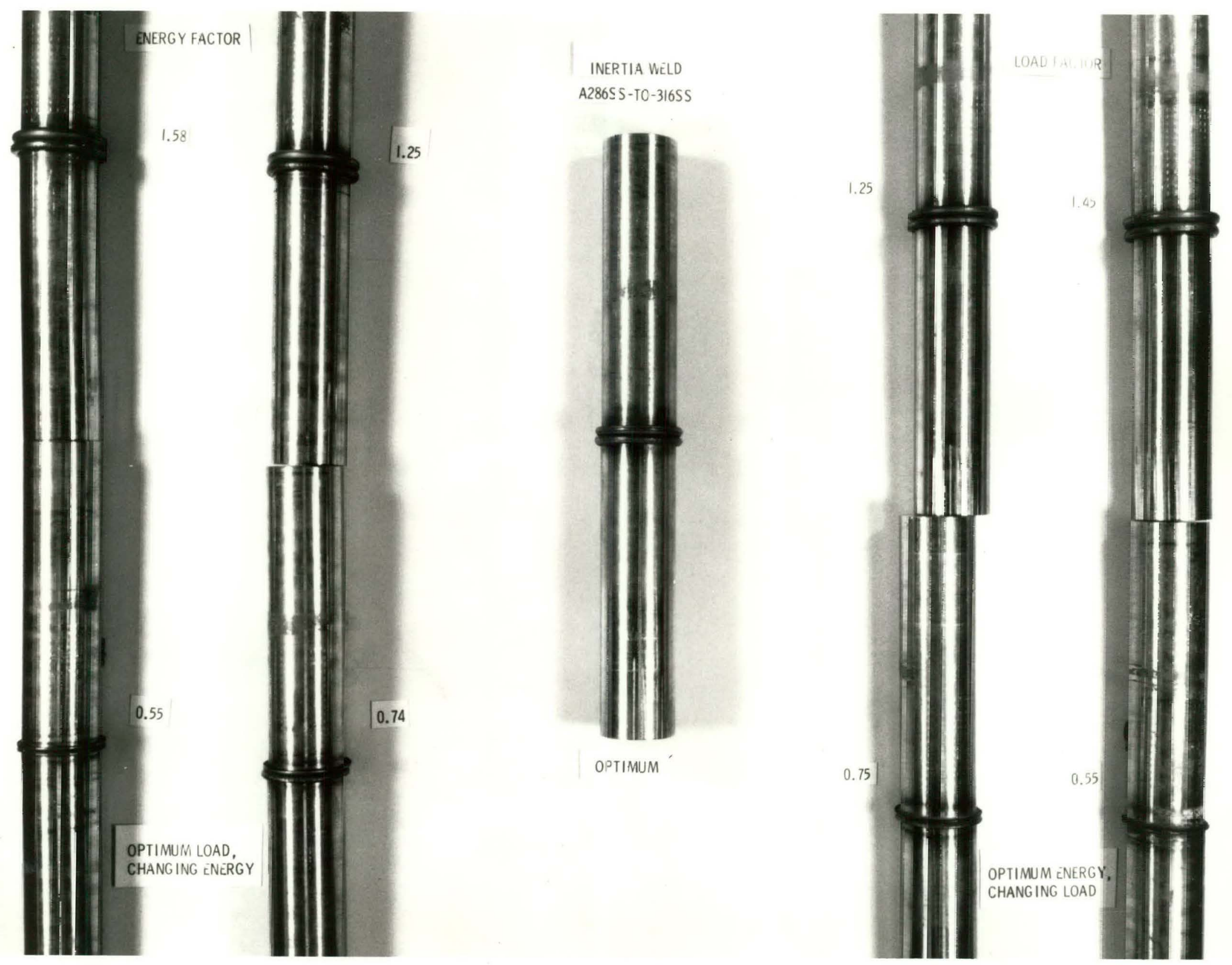

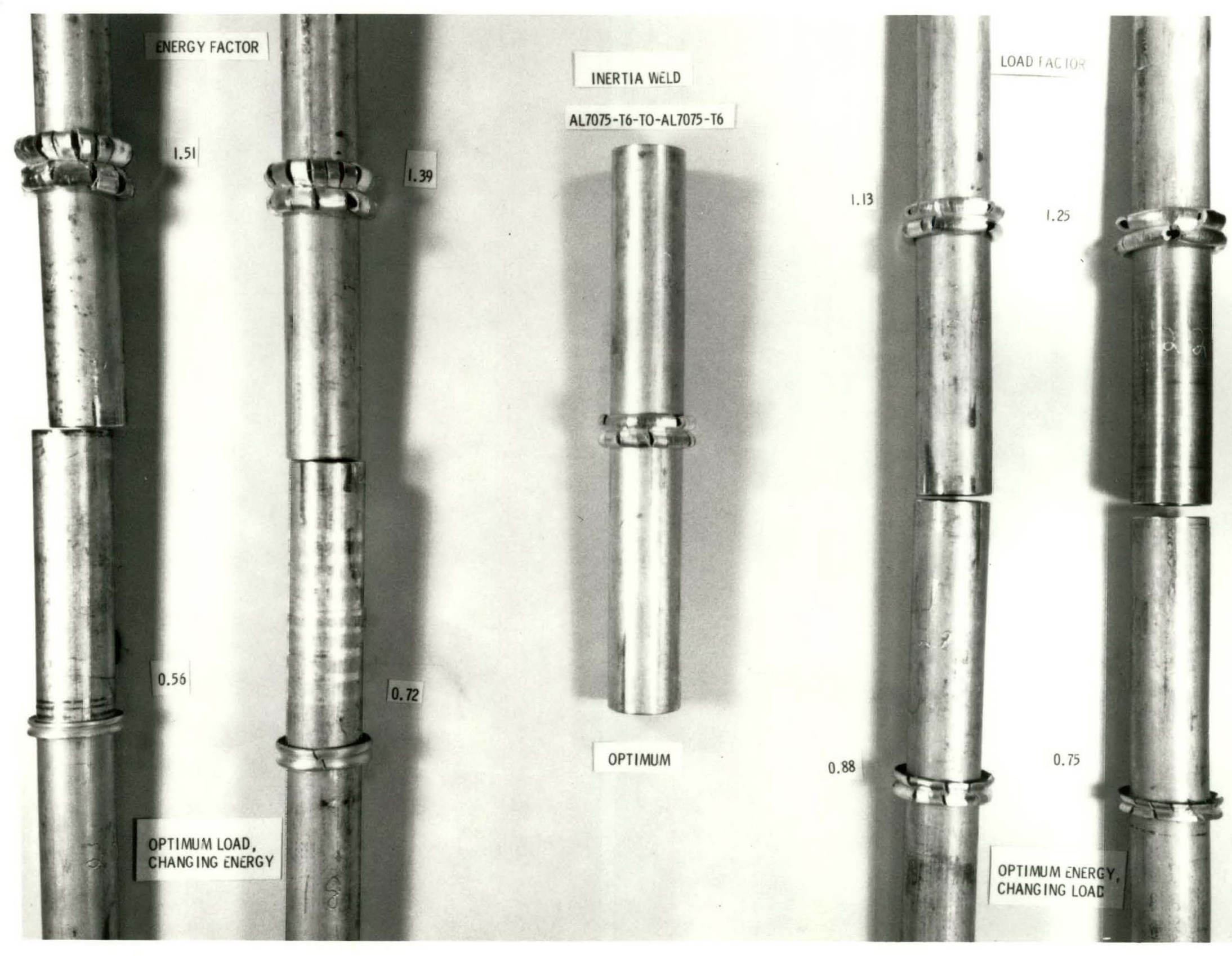

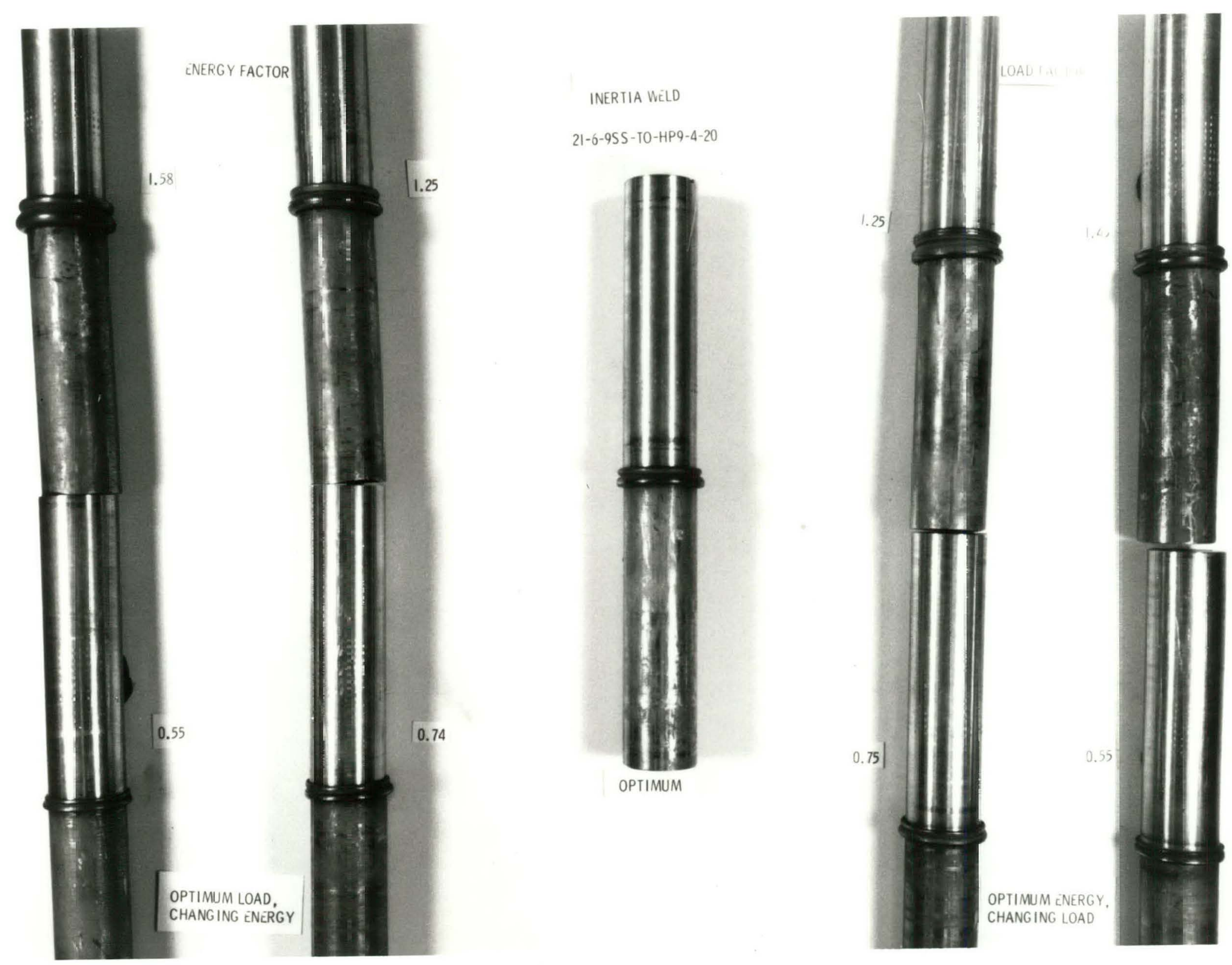

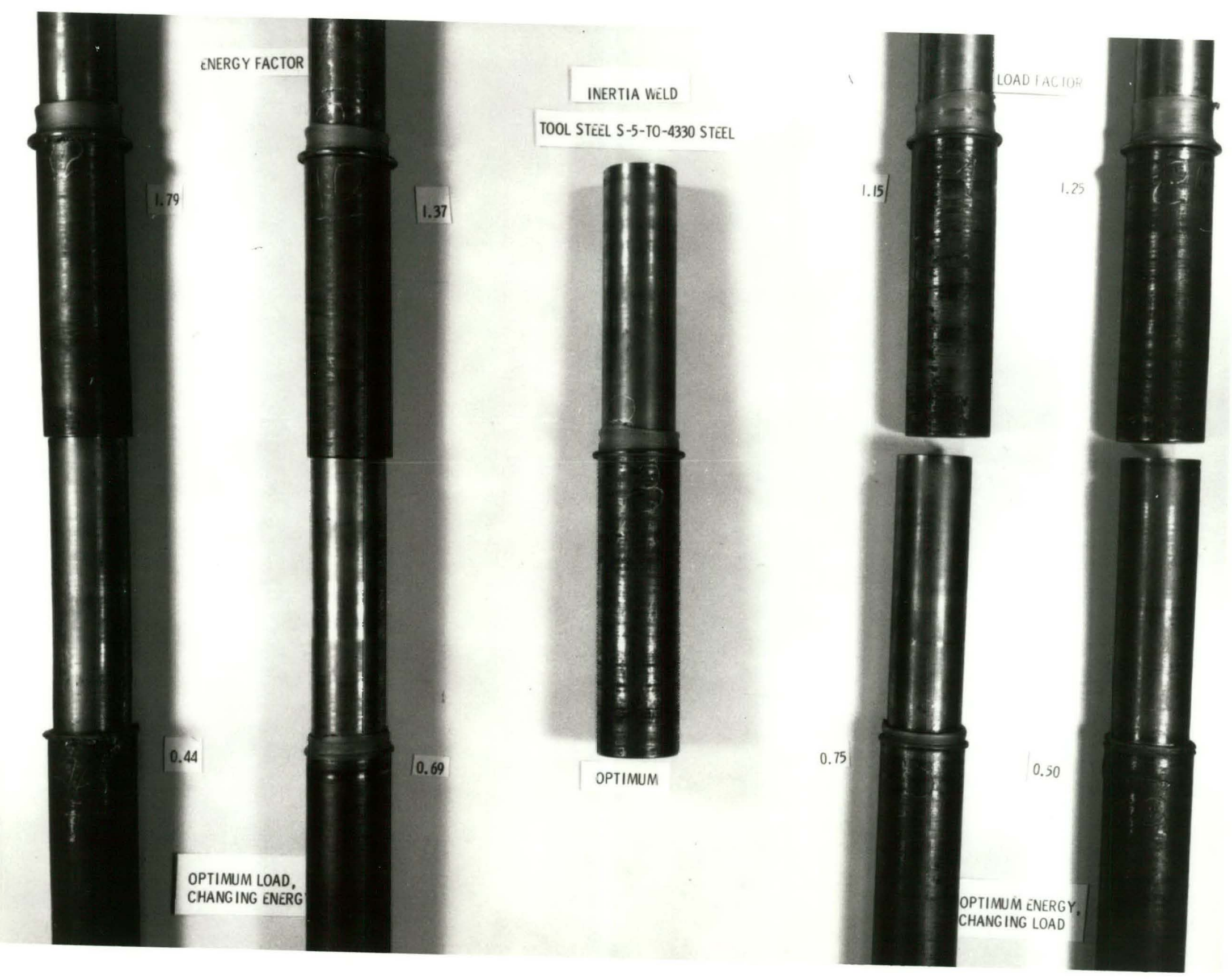


A review of Figures 2-11 shows that all the changes in parameters produced easily recognizable changes in the configuration of the weld expulsion. In the more readily weldable pairs the smaller variations were around 25 percent, while in the more difficult combinations, the smaller variations were less than 10 or 15 percent. Nevertheless, in all cases the differences in appearance are easy to recognize and could form the basis for post-weld inspection.

Table III presents the amount of upset in thousandths of an inch, related to the weld parameters and variation factors and to the breaking stress in psi. The center two columns list for each weld pair the welding energy, the welding axial stress, and the amount of upset and breaking stress for the eight welds made with the optimum parameters. Upset and breaking stress are presented as an average of the eight weldments with the maximum and minimum. Within each group of eight, the scatter in upset was less than \pm 10 percent, with two or three exceptions.

While the presence of the weld flash and its built-in notch served to confine the failures to the weld region (for the most part), the breaking strengths were usually consistent with or better than the expected strength of the base metal. Notable exceptions are the high-strength steels (4330-toHP 9-4-20 and 4330-to-tool steel) in which many fractures were initiated by the hydraulic pressure actuated grips crushing the hollow samples and cracking them. Nevertheless the variation in breaking stress (load divided by the nominal area of smaller member) was surprisingly small within the group of eight. It is likely that more time spent optimizing the parameters and heat treatment of some pairs would surely have reduced the scatter in both upset and strength of these weldments. More careful measurement of upset might have reduced the scatter in the values. A better preparation of tensile test specimens, with flash removed both inside and outside, would surely have moved the failures completely away from the weld in most cases. Even so, the fracture was never at the weld interface in any of the "optimum" welds except for the titanium samples.

As the weld parameters were varied, the upset varied as expected, just as the weld protrusion appearance did. As energy and force were increased, the upset increased and vice versa. In many cases a plot of upset-versus-energy or upset-versus-load is a reasonable straight line. We have not chosen to present the data in that fashion because the experiment was not planned with that purpose, and we cannot verify, now that the specimens have been broken, that the data are accurate enough for such treatment. The data clearly suggest, however, that for a given weld a reasonably precise relationship can be developed between amount of upset and either weld energy or axial force for some considerable variation on either side of the optimum value.

We present joint breaking stress values in a similar vein, not to advertise possible strength levels but merely to show that only in the extremes of parameter variations was the strength adversely affected (and even then not always). The reported values must be considered with some caution. For example, the failure stress of Items $2,3,5,6,8$, and 10 all exceeded the anticipated strength of the weaker member. For 2 and 3 , the extra thickness of the 6061 and the copper respectively allowed the base metal to support a larger load, thereby raising the interface stress above the typical ultimate strength of the material. In $5,6,8$, and 10 , however, the reported stress 
TABLE III

WELO PARAMETERS, VARIATIONS, AND RESULTANT UPSET AND BREAKING STRESSa

\begin{tabular}{|c|c|c|c|c|c|c|c|c|c|c|c|c|c|c|c|c|}
\hline \multirow{3}{*}{ No. } & \multirow{2}{*}{\multicolumn{2}{|c|}{ Weld Pair }} & \multirow{2}{*}{\multicolumn{4}{|c|}{$\begin{array}{c}\text { Energy Factorb } \\
\text { Upset } \\
\text { Fracture Stress }\end{array}$}} & \multicolumn{5}{|c|}{ Design Parameters } & & \multicolumn{4}{|c|}{ Load Factorb } \\
\hline & & & & & & & \multirow{2}{*}{ Energy } & \multicolumn{2}{|c|}{$\frac{\text { Upset }}{\text { Frac. Str. }}$} & \multicolumn{3}{|c|}{$\begin{array}{r}\text { Axiat } \\
\text { Stress }\end{array}$} & \multicolumn{4}{|c|}{$\begin{array}{c}\text { Upset } \\
\text { Fracture Stress }\end{array}$} \\
\hline & 4330 & HP $9-4-20$ & 1.54 & 1.18 & 0.73 & 0.55 & & & & & 16 & & 1.18 & 1.36 & 0.83 & 0.64 \\
\hline & & & $420 / 427$ & $322 / 344$ & $196 / 202$ & $139 / 140$ & & 256 & $\frac{266}{247}$ & & & & $224 / 293$ & $293 / 303$ & $220 / 228$ & $190 / 193$ \\
\hline & $\cdot$ & & $149 / 151$ & $148 / 152$ & $134 / 139$ & $146 / 146$ & & 147 & $\frac{151}{144}$ & & & & $146 / 151$ & $130 / 146$ & $148 / 151$ & $147 / 150$ \\
\hline \multirow[t]{3}{*}{2} & 31655 & Al-6016-T6 & 1.44 & 1.14 & 0.87 & 0.64 & 6 & & & & 30 & & 1.22 & 1.44 & 0.78 & 0.56 \\
\hline & $\cdot$ & & $114 / 136$ & $77 / 82$ & $38 / 44$ & $17 / 18$ & & 67 & $\frac{90}{53}$ & & & & $90 / 90$ & $126 / 133$ & $39 / 48$ & $23 / 31$ \\
\hline & & & $46 / 38$ & $28 / 48$ & $53 / 33$ & $6 / 7$ & & 54 & $\frac{62}{46}$ & & & & $49 / 39$ & $53 / 50$ & $51 / 34$ & $54 / 17$ \\
\hline \multirow[t]{3}{*}{3} & $316 \mathrm{SS}$ & Copper & 1.44 & 1.21 & 0.81 & 0.64 & 36 & & & & 22 & & 1.15 & 1.31 & 0.85 & 0.69 \\
\hline & & & $570 / 575$ & $475 / 475$ & $232 / 258$ & $137 / 169$ & & 335 & $\frac{372}{301}$ & & & - & $397 / 398$ & $475 / 477$ & $330 / 350$ & $285 / 280$ \\
\hline & & & $58 / 62$ & $54 / 58$ & $44 / 52$ & $12 / 40$ & & 53 & $\frac{54}{49}$ & & & & $17 / 52$ & $34 / 39$ & $48 / 53$ & $43 / 50$ \\
\hline \multirow[t]{3}{*}{4} & $T i-6-6-2$ & Red Brass & 1.78 & 1.36 & 0.69 & 0.44 & 4.5 & & & & 112 & & 1.07 & 1.11 & 0.93 & 0.89 \\
\hline & & & $313 / 318$ & $217 / 248$ & $95 / 95$ & $75 / 78$ & & 152 & $\frac{170}{130}$ & & & & $183 / 238$ & $187 / 193$ & $106 / 107$ & $81 / 92$ \\
\hline & & & -- & - & -- & -- & & & . & & · & & -- & -- & -- & -- \\
\hline \multirow[t]{3}{*}{5} & $A-286$ & $A-286$ & 1.45 & 1.25 & 0.74 & 0.55 & 37 & & & & 16 & & 1.25 & 1.45 & 0.75 & 0.55 \\
\hline & & & $365 / 367$ & $267 / 267$ & $122 / 129$ & $60 / 68$ & & 203 & $\frac{214}{192}$ & & . & & $256 / 267$ & $308 / 310$ & $121 / 125$ & $55 / 56$ \\
\hline & & & $141 / 144$ & $139 / 150$ & $135 / 135$ & $119 / 129$ & . & 136 & $\frac{139}{133}$ & 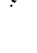 & + & & $145 / 146=$ & $154 / 159$ & $122 / 126$ & $8 / 8$ \\
\hline \multirow[t]{3}{*}{6} & A-286 & 31655 & 1.58 & 1.28 & 0.74 & 0.55 & 37 & & & & 16 & & 1.25 & 1.45 & 0.75 & 0.55 \\
\hline & & & $335 / 387$ & $269 / 269$ & $102 / 112$ & $69 / 75$ & & 196 & $\frac{211}{149}$ & & $\therefore$ & & $253 / 269$ & $351 / 355$ & $90 / 98$ & $36 / 39$ \\
\hline & & . & $79 / 79$ & $75 / 78$ & $77 / 74$ & $73 / 78$ & & 77 & $\frac{82}{73}$ & & & & $81 / 84$ & $83 / 88$ & $66 / 72$ & $63 / 62$ \\
\hline \multirow[t]{3}{*}{$7 \mathrm{~A}$} & $7075-\mathrm{T} 6$ & A) $7075-\mathrm{T} 6$ & 1.61 & 1.39 & 0.72 & 0.56 & 17 & & & & 11 & & 1.13 & 1.25 & 0.88 & 0.75 \\
\hline & . & & $1130 / 1135$ & $993 /$ - & $310 / 318$ & $215 / 220$ & • & 518 & $\frac{541}{467}$ & . & & & $662 / 668$ & $747 / 770$ & 375़/395 & $293 / 300$ \\
\hline & o & & $68 / 69$ & $70 / 74$ & $77 / 79$ & $76 / 76$ & & 78 & $\frac{80}{77}$ & + & & & $77 / 78$ & $71 / 79$ & $74 / 76$ & $70 / 73$ \\
\hline \multirow[t]{3}{*}{8} & $21-6-9 S S$ & $9-4-20$ & 1.58 & 1.25 & 0.74 & 0.55 & 38 & & & & 16 & & 1.25 & i. 45 & 0.75 & 0.55 \\
\hline & & & $474 / 507$ & $342 / 342$ & $173 / 186$ & $123 / 129$ & & 243 & $\frac{257}{232}$ & , & & & $302 / 308$ & $343 / 350$ & $177 / 204$ & $109 / 135$ \\
\hline & & & $136 / 137$ & $125 / 128$ & $119 / 137$ & $127 / 137$ & & 131 & $\frac{139}{125}$ & & & & $124 / 137$ & $125 / 131$ & $126 / 131$ & $125 / 128$ \\
\hline \multirow[t]{3}{*}{9} & Sool Steel & 4330 & 1.79 & 1.37 & 0.69 & 0.44 & 39 & & & & 34 & & 1.15 & 1.25 & 0.75 & 0.50 \\
\hline & & & $364 / 370$ & $280 / 287$ & $138 / 140$ & $90 / 90$ & & 209 & $\frac{216}{203}$ & & & & $247 / 258$ & $272 / 274$ & $155 / 168$ & $120 / 122$ \\
\hline & & & $68 / 233$ & $102 / 221$ & $122 / 126$ & $168 / 204$ & & 153 & $\frac{184}{126}$ & & & & $232 / 237$ & $87 / 195$ & $64 / 86$ & $33 / 38$ \\
\hline \multirow[t]{3}{*}{10} & 1) 2024-T6 & A) 2024-T6 & 1.58. & 1.33 & 0.72 & 0.56 & 16 & & & & 11 & & 1.13 & 1.27 & 0.87 & 0.73 \\
\hline & & & $925 / 925$ & $535 / 560$ & $170 / 175$ & $161 / 165$ & & 293 & $\frac{302}{2 / 5}$ & & $\cdot$ & $\cdot$ & $400 / 400$ & $530 / 535$ & $192 / 200$ & $118 /=$ \\
\hline & & & $65 / 64$ & $70 / 70$ & $63 / 63$ & $7 / 7$ & & 69 & $\frac{70}{68}$ & & & & $20 / 65$ & $70 / 72$ & $65 / 67$ & $58 / 63$ \\
\hline
\end{tabular}

\footnotetext{
a For each weld pair the top row shows the design energy (in $10^{3} \mathrm{lb}-\mathrm{ft} /$ in. ${ }^{2}$ ) for the elght "optimum" welds, with the multiplier (factor) applied appearing in the four columns to the left of center, and the axial stress (in ksi) applied in making the eight joints, with the factors applied for the four pairs of varying welds in the four columns to the right of center. The second row for each pair ifsts in each of the four columns to the left and right of center the amount of upset (in $10^{-3}$ in.) observed for each weld made with the energy or load factor appearing just above it. The third row lists the tensile breaking stress (in ksi) for each of the two welds. The very center column presents the average upset and the limits of the elght specimens (second ifne) and the average strength and the limits of the eight specimens made using the optimum energy and axial stress (third line).

b When the Energy was varied as indicated by the factor of the "Design", the Load was held constant at the "Design" level, and vice versa.
} 
applies to the base metal as well as the weld, and it is not clear why A-286, 316 , and 21-6-9 stainless steels were so strong, nor why they did not fail consistently away from the weld. (The normal variability of metals could account for the slightly elevated strength of the 2024.) Therefore, the actual strength values should not be used outside this experiment, except in a most general way.

\section{Conclusions}

The principal conclusion we wish to draw from this experiment is that, when a good set of "optimum" weld parameters have been developed, joint strength is adversely affected only by large deviations from the "optimum" parameters. Furthermore, these variations produce easily measured changes in upset, and readily observed changes in weld protrusion configuration.

We do not claim that the parameters for "design" or "optimum" were adequately optimized, and we do not recommend any of them, but rather suggest that anyone interested in applying inertia welding to any of the combinations approach them carefully and develop their own "optimum" parameters.

We believe that this experiment confirms that all these combinations can be welded except for the titanium to brass. Conventional welding procedures are not recommended for Items 2 through 7 , and 10, and seldom recommended for 1,8 , and 9. We have subsequently had this titanium alloy welded to this brass (Item 4 ) by a different contractor, Interface Welding of Carson, CA, with much greater but still limited success (and much different parameters). The same contractor welded the titanium alloy to unalloyed copper, with all failures occurring in the copper with stresses exceeding that of the strength of the copper (as in Item 3).

From all these we are assured that the process is very forgiving, that it can be readily monitored ( $r p m$ and axial force), and that the product can be inspected to demonstrate that each weld was made with the proper parameters. High quality hardware stili requires adequate control of the stuck and its heat treatment and of appropriate heat treatment of the weld. These requirements do not introduce anything. new, however. There may still be a need for nondestructive evaluations of some welds (heat treatment cracking, for example), but the absence of a predetermined proven nondestructive inspection technique does not preclude the selection of this process in critical joints. 


\section{REFERENCES}

1. W. M. Hallet, "A Review of Inertia Welding," Society of Manufacturing Engineers, Technical Paper Ad 76-909 (1976).

2. K. R. Fitzgerald, "Friction Welding Saves Money and Metal," Design News, June $18,1979$.

3. E. Hoeffer, "Inertia Welding for Marine Engineering," American Machinist, April 1, 1974.

4. J. Wessling, "Inertia Welding Coming of Age for Jets," Metal Working News, March 10, 1969. 
UNLIMITED RELEASE

INITIAL DISTRIBUTION

Freight Master

8600 Will Rogers Blvd.

Box 40555

Ft. Worth, TX 87140

Attn: Stephen Harper

Interface Welding

20701 S. Annalee

Carson, CA 90746

Attn: Al S. Wadleigh

Manufacturing Technology, Inc.

230 W. McKinley

Mishawaka, IN 46544

Attn: Dan Kuruzar

Union Carbide Corporation

Y-12 Plant

Oak Ridge, TN 37830

Attn: Tom. Mustaleski

M. J. Davis, 5830; Attn: J. L. Ledman, 5836

R. E. Fisher, 5833

R. C. Hennig, 5833

J. L. Jellison, 5833

F. J. Zanner, 5836

T. B. Cook, 8000; Attn: D. M. 01 son, 8100

A. N. Blackwell, 8200

L. Gutierrez, 8400

J.F. Barham, 8110; Attn: D. J. Bohrer, 8111

J. D. Gilson, 8112

J. L. Wirth, 8150; Attn: L. Hiles, 8116

A. Jones, 8116
L. Hiles, 8151 .

G. N. Beeler, 8152

R. D. Cozine, 8160; Attn: A. S. Rivenes, 8162

B. F. Murphey, 8300; Attn: R. L. Rinne, 8320

D. M. Schuster, 8310

G. W. Anderson, 8330

D. A. Nissen, 8312

M. W. Mote, 8312 (10)

R. W. Mar, 8313

A. J. West, 8314

L. A. West, 8315

J. C. Swearengen, 8316

L. N. Tallerico, 8415

D. E. Gregson, 8440; Attn: D. J. Havlik, 8441

W. R. Hoover, 8442

W. G. Wilson, 8453

H. Hanser, 8445 
Publications Division, 8265, for TIC (2)

Publications Division, 8265/Technical Library Processes Division, 3141

Technical Library Processes Division, 3141

M. A. Pound, 8214, for Central Technical Files

(3) 


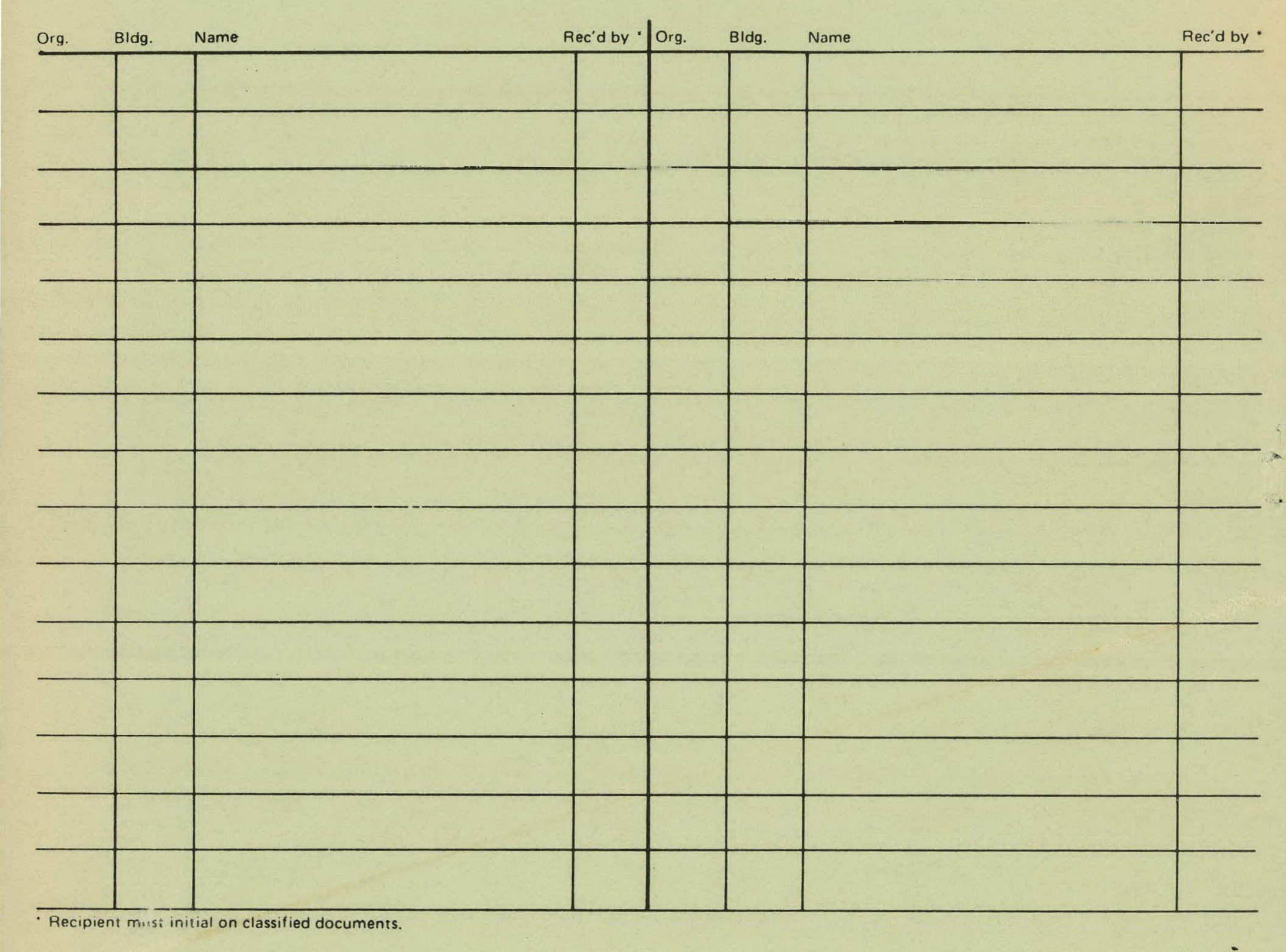

